https://doi.org/10.5817/NR2019-1-7

\title{
Категория состояния в древнерусских памятниках
}

УШАКОВА, О.: Функционирование слов категории состояния в древнерусских памятниках XII-XVII вв. Brno: Masarykova univerzita, 2016. ISBN 978-80-2 10-7575-7.

Категория состояния - это специфическая группа знаменательных слов, которые выражают статутальный признак, а в предложении выполняют предикативную функцию. Проблематика категории состояния охватывает целый ряд спорных моментов, в частности, вопрос о положении категории состояния в грамматической системе русского языка, о лексическом составе данной категории, о морфологическом наполнении этой группы слов, об их деривационных механизмах образования.

Интерес к данным единицам слов проявился еще в прошлом столетии: внимание этой группе уделил в своих работах А.А.Шахматов. Об особенностях функционирования таких слов писал А. М. Пешковский. Особый вклад в разработку данного вопроса внес Л.В.Щерба. Именно он выделил эту группу слов в особый лексико-грамматический класс и предложил термин «категория состояния». Дальнейшими изысканиями в данной области занимался В.В. Виноградов, который вместе с Л. В. Щербой считают данную категорию слов самостоятельной частью речи, располагающей по Виноградову также грамматическими категориями времени и наклонения. Синтаксические и морфологические особенности категории состояния исследовали Е. М. Галкина-Федорук, В. В. Бабайцева, В. А. Белошапкова. Однако несмотря на внимание исследователей к этой теме, вопрос о категории состояния остается проблемной областью лингвистики.

Целью настоящей работы является системное рассмотрение в историческом плане функционирование слов категории состояния в истории русского языка на материале выбранных древнерусских текстов. Поставленная цель предполагает решение теоретических и практических задач. Их описание приводится на практическом материале, собранном по летописным и агиографическим памятникам, которые были созданы с XII по XVII вв., т.е. именно в тот период, когда в древнерусском языке происходило формирование базовых грамматических категорий. Для анализа поступило 16 источников, которые перечислены в ведении работы [UŠAKOVA 2016, 8]. Предусмотренный анализ предполагал изыскания системного характера, т.е. исследование единиц в лексико-семантическом, морфемно-морфологическом и синтаксическом аспектах. Автором было зафиксировано в выбранных текстах 467 конструкций, 
в которых слова, выполняющие предикативную функцию и выражающие состояние, встречаются 519 раз.

Настоящая монография состоит из трех главных частей. В первой (Лексико-семантическая категория слов категории состояния [UŠAKOVA 2016, 13-37]) легло в основу классифицирования по лексико-сематическим разрядам более узкое, дифференцированиое лексическое значение, выражаемое анализируемыми лексемами (состояние человека, природы, окружающей среды, состояние или оценка какого-то действия или события, выражение модально-волевых характеристик действия). На основании анализа собранного материала автор утверждает, что слова категории состояния группируются вокруг нескольких сематических «узлов».

Системные отношения, наблюдаемые на уровне лексики любого языка, обнаруживаются и между собранными автором единицами корпуса. Автор анализирует их лексико-семантические связи, которые могут быть парадигматического (внимание обращено на синонимы, ср.: добро-благо, страшно-ужасно, и антонимы, ср,: темно-светло, добро-зло, засвидетельствованы в собранном материале) и синтагматического характера (проявляются в сочетании слов друг с другом, последовательно соединяются определенные слова категории состояния и некоторые инфинитивы, ср.: И бю страшно виджти дәвп силь великиа...).

Слова категории состояния подверглись формальным и семантическим изменениям. Автору следовало проследить историческое развитие лексем собранного корпуса. У ряда слов наблюдаются сдвиги в лексическом значении (ср.: неудобно, нелюпо), некоторые лексемы полностью вышли из употребления (ср.: лзп, потребно, люпо).

Исследования единиц категории состояния в рамках морфемно-морфологического аспекта проведено во второй части монографии (Морфемно-морфологические особенности слов категории состояния [UŠAKOVA 2016, 39-51]). Оно предполагает, с одной стороны, выявление деривационных механизмов рассматриваемых слов, анализ их словообразовательной структуры, описание системных взаимоотношений морфем в рамках слов категории состояния, с другой стороны, изучение морфологической парадигмы анализируемых единиц и способов их образования, а также грамматических категорий, обнаруживаемых у данного разряда слов. Хотя одним из релевантных признаков является их морфологическая неизменяемость, ядро этого класса слов составляют отадъективные образования, что обусловило у них наличие категории степеней сравнения (ср.: добрпе, полезнее, луче // луттче // лучшп // лютчи // лучши // лучше // лутчи // лутши; велми студено, зюло страшно, премрачно, предивно). 
Доминантным показателем данного класса слов представляется их синтаксическая функция. Можно их отличить от единиц других грамматических классов - кратких прилагательных, наречий, существительных и кратких причастий. Анализ синтаксических особенностей слов категории состояния рассмотрен в третьей части монографии (Синтаксические признаки слов категории состояния [UŠAKOVA 2016, 53-90]). В первую очередь рассмотрены синтаксические структуры, в которых фиксируются исследуемые слова. Их традиционной синтаксической функцией является роль предиката безличных односоставных предложений. Большая часть примеров собранного автором корпуса представлена такими конструкциями (ср.: Они же рекоша: «Гдь mи любо?»). Слова категории состояния здесь выполняют функцию предиката односоставного предложения. Однако обнаруживается проблематичная группа конструкций, а именно где слово категории состояния сочетается с инфинитивом. Такие структуры могут быть истолкованы как односоставные безличные, либо как двусоставные, в которых инфинитив выступает в качестве подлежащего, а слово категории состояния функционирует как именное сказуемое. Здесь важным оказывается позиция инфинитива и порядок слов. С типологической точки зрения по данным автора можно сказать, что слова категории состояния могут выступать не только в позиции главного члена безличного предложения, но и использоваться в качестве составного именного сказуемого двусоставного предложения; слова категории состояния употребляются со связочным элементом (ср.: Лучши ти есть смириться, неже рать составляти на дядю своего). Единственным связочным глаголом оказался в собранном материале глагол «быти», реализирующийся в форме настоящего и будущего времени, далее в форме аориста, имперфекта, перфекта, плюсквамперфекта, а также в форме условного наклонения. С коммуникативной точки зрения наиболее употребительными оказались повествовательные предложения; это вызвано жанровыми канонами исследуемых текстов. Однако слова категории состояния представлены во всех типах высказываний. Это свидетельствует о том, что диапазон их употребления не ограничивается ни лексическими, ни грамматическими рамками.

С семантико-синтаксической валентности слова категории состояния выступают в качестве предикативного центра безличного предложения. Подобно глаголам они способны иметь при себе дополнение. В работе засвидетельствованы дополнения, выраженные различными падежными формами. Наиболее частотным оказалось дополнение, выраженное беспредложной формой родительного падежа синтаксического существительного (ср.: Аще ти не жаль очины своея, ни матере, стары суща, и дйтий своих). Формы иных падежей встречаются редко. Дополнение при словах категории состояния можно разделить на два 
типа: объектный и субъектный. Объектное дополнение засвидетельствовано в разных падежах, субъектное - всегда в форме дательного падежа (ср.: А Пьсковичемъ однымъ не мочно бяше пособити Изборяномъ). Предикативная функция слов категории состояния предполагает, что анализируемые слова могут быть распространены обстоятельствами. В собранном материале наиболее частотными оказались обстоятельственные компоненты места (ср.: В Новгородъ выложиша вси князи въ свободу: кде имъ любо, ту же собп князя поимають) и времени (ср.: Того же лғта бысть мирно). В анализируемых памятниках были обнаружены и другие типы обстоятельственных распространителей (обстоятельства образа действия, причины, меры и степени). Таким образом, автором было рассмотрено в синтаксическом аспекте функционирование слов категории состояния в избранных древнерусских летописях и житиях.

В заключении [UŠAKOVA 2016, 91-93] подытожены результаты научного исследования. В списке использованной литературы [UŠAKOVA 2016, 95-101] приводятся источники исследования, русскоязычные источники, чешскоязычные и словацкоязычные источники, словари и национальные корпусы слов. Затем следует англоязычное резюме.

Автор опиралась в своем исследовании на практический материал, выбранный из древнерусских памятников XII-XVII вв. В качестве основного источника послужили летописные и агиографические тексты указанного периода. В приложении к монографии [UŠAKOVA 2016, 130-138] дается список и краткая характеристика летописных и агиографических памятников, которые были автором выбраны для изучения категории состояния. Приводится выборка конструкций, обнаруженных в указанных памятниках. В самом конце находится предметный указатель [UŠAKOVA 2016, 139-140], содержащий лингвистические термины, которые употребляются на страницах настоящей монографии.

Автор рецензируемого труда предъявила надежную и добросовестную работу, в которой подробно проанализирована избранная проблематика. Она может стать фундаментом для всех, кто будет интересоваться подобной тематикой.

Алеш Бранднер

\section{Библиография:}

UŠAKOVA, O. (2016): Funkcionirovanije slov kategorii sostojanija $v$ drevnerusskich pamjatnikach XII-XVII vv. Brno. 